OPEN ACCESS

Edited by:

Shang $X u$,

China University of Petroleum, China

Reviewed by:

Tian Dong,

China University of Geosciences

Wuhan, China

Zhen Qiu,

Research Institute of Petroleum Exploration and Development (RIPED),

China

*Correspondence:

Lei Chen

cl211@126.com

Specialty section: This article was submitted to

Economic Geology,

a section of the journal

Frontiers in Earth Science

Received: 14 September 2021

Accepted: 18 October 2021

Published: 29 November 2021

Citation:

Tang Q, Zhou L, Chen L, Tan X and

Wang $G$ (2021) Development

Characteristics of Shale Lithofacies in the Longmaxi Formation and their Main Controlling Factors in the Changning Area, South Sichuan Basin, SW China.

Front. Earth Sci. 9:775657.

doi: 10.3389/feart.2021.775657

\section{Development Characteristics of Shale Lithofacies in the Longmaxi Formation and their Main Controlling Factors in the Changning Area, South Sichuan Basin, SW China}

\author{
Qingsong Tang ${ }^{1,2}$, Lu Zhou ${ }^{1}$, Lei Chen ${ }^{1,3,4 *}$, Xiucheng Tan ${ }^{1,3,4}$ and Gaoxiang Wang ${ }^{1,2}$ \\ ${ }^{1}$ School of Geoscience and Technology, Southwest Petroleum University, Chengdu, China, ${ }^{2}$ PetroChina Southwest Oil \& Gas \\ Field Company, Chengdu, China, ${ }^{3}$ Natural Gas Geology Key Laboratory of Sichuan Province, Southwest Petroleum University, \\ Chengdu, China, ${ }^{4}$ Division of Key Laboratory of Carbonate Reservoirs, CNPC, Southwest Petroleum University, Chengdu, China
}

Based on core observations, thin sections, X-ray diffraction (XRD), and seismic data, the lithofacies types in the organic-rich Longmaxi shale (Lower Silurian) in the Changning area of the southern Sichuan Basin were identified. The factors controlling the spatial variations in the shale lithofacies and the influences of the shale lithofacies on shale gas development were also analyzed. Results indicate that there are seven main types of shale lithofacies in the Long11 sub-member of the Longmaxi Formation, including siliceous shale (S-1), mixed siliceous shale (S-2), carbonate-rich siliceous shale (S-3), clay-rich siliceous shale (S-4), carbonate/siliceous shale (M-1), mixed shale (M-2), and argillaceous/siliceous shale (M-4). A vertical transition from the carbonate shale association + mixed shale association at the bottom of the sub-member to a siliceous shale association and mixed shale association + siliceous shale at the top generally appears in the Long11 sub-member. The shale lithofacies of the Long11 sub-member also laterally change from the central depression (low-lying area) to the geomorphic highland in the east and west parts of the Changning area. The spatial variations in shale lithofacies in the Long11 sub-member of the Changning area were mainly controlled by palaeogeomorphology and relative sea level. The geomorphic highland area is dominated by carbonate-rich siliceous shale and mixed siliceous shale, but the depression (low-lying area) is mainly dominated by mixed siliceous shale and argillaceous/carbonate shale.

Keywords: shale, lithofacies, Longmaxi Formation, Silurian, south Sichuan Basin

\section{INTRODUCTION}

Marine shales in China, which are characterized by a wide distribution, high thickness, high thermal maturity, high organic matter content, and strong hydrocarbon generation ability, show great potential for shale gas exploration and development (Nie et al., 2010; Nie and Zhang, 2010; Zou et al., 2010; Dong et al., 2015a; Zou et al., 2015; Dong et al., 2016; Wang et al., 2016; Zou et al., 2016; Dong et al., 2018; Ma, 2019; Qiu and Zou, 2020a; Qiu and Zou, 2020b; Jiang et al., 2020). The Lower Silurian Longmaxi Formation is one of the most important strata for shale gas exploration and development in South China, which has successfully produced commercial shale gas flows since 2012 
and was appraised as one of the national marine shale gas demonstration zones in China (Dai et al., 2014; Guo and Zhang, 2014; Chen et al., 2020; Liu et al., 2021a).

As the basis for geological research on shale gas, the development characteristics, temporal and spatial distribution, and main controlling factors of shale lithofacies have great significance for reconstructing shale depositional process and are the keys to search for shale gas "sweet spots" (Sahoo et al., 2013; Wang et al., 2020a; Buntoro et al., 2020; Gou et al., 2020; Wang et al., 2021a; Wu et al., 2021). Due to the importance of shale lithofacies, many scholars have studied shale lithofacies from the aspects of classification schemes, quantitative characterizations, and lithofacies reservoir differences (Wang et al., 2002; Hickey and Henk, 2007; Wang and Carr, 2012a; Wang and Carr, 2012b; Wang and Carr, 2013; Wang et al., 2013; Wang et al., 2014; Wu et al., 2016; Gou et al., 2019; Long et al., 2021). However, most studies have focused on the classification schemes, characteristics, reservoir property variations, and prediction methods of shale lithofacies (Loucks and Ruppel, 2007; Dong et al., 2015b; Bruner et al., 2015; Du et al., 2015; Zhu et al., 2018; Yang et al., 2019; Xu et al., 2020a; Xu et al., 2020b; Liu et al., 2020c; Gou et al., 2020). Few studies have been examined the temporal and spatial distributions and main controlling factors of shale lithofacies (Wang et al., 2013; Wang et al., 2018; Liu et al., 2020d).

As the most important shale gas exploration target strata, the Longmaxi Formation has attracted interest from numerous petroleum geologists. Increasing numbers of studies have confirmed that the Longmaxi shale exhibits strong heterogeneity, which is the key reason that led to different quality shale reservoirs formed in the Longmaxi Formation (Chen et al., 2015a; Xu et al., 2019; Liu et al., 2020a; Liu et al., 2020b; Liu et al., 2021b). Due to the strong heterogeneity of shale reservoirs from the macroscale to microscale, it is difficult to predict the effective shale gas reservoirs (Chen et al., 2015b; Tang et al., 2016). However, as the basic unit of shale, a shale lithofacies constitutes a shale reservoir, which reflects the geochemical, geological, and petrophysical information (Tang et al., 2016). Based on outcrops, drilling cores, thin sections, geochemical data, well logs, and seismic data, many scholars have researched the shale lithofacies of the Longmaxi Formation in the Sichuan Basin. However, most of these studies have focused on the classifications, descriptions, and comparisons of these shale lithofacies (Tang et al., 2016; Ou et al., 2018; Zhang et al., 2018; Hu et al., 2019; Wang et al., 2020b; Feng et al., 2020), and have rarely involved the temporal and spatial evolution of these shale lithofacies (Wang et al., 2018).

In this paper, the organic-rich shale section in the Long11 submember of the Longmaxi Formation was analyzed in the Changning area in the southern Sichuan Basin. Fine classifications were carried out for the shale lithofacies types by using core observations, thinsection analysis, and X-ray diffraction (XRD). The characteristics, vertical development patterns, and spatial distributions of shale lithofacies and main controlling factors of shale lithofacies development in the Changning area were analyzed.

\section{GEOLOGICAL SETTING}

The Sichuan Basin, which is located on the southwestern margin of the Yangtze Platform, is a complex marine and terrestrial superposed basin with stratigraphical sequence of Presinian metamorphic rocks as the basement, marine carbonate rocks from the Sinian to Middle Triassic, and continental clastic rocks from the Late Triassic to Eocene (Wang et al., 2002). From the Late Ordovician to Early Silurian, the Yangtze Plate collided with Cathysia, which resulted with the uplift of the Yangtze Plate in the northwest and downward deformation in the southeastern margin, leading to a deep-water sedimentary environment formed in the Upper Yangtze Platform (referred to as the Yangtze Sea by Li et al., 2021) (Figure 1A). Bounded by the Chuanzhong uplift, Qianzhong uplift, and Xuefeng uplift and separated by the interior submarine high of the Hunan-Hubei Arch, the Yangtze Sea evolved from a shallow carbonate platform into a semi-isolated and siliciclastic-dominated cratonic basin from the Late Ordovician to Early Silurian (Li et al., 2021). During the Early Silurian, due to the restricted exchange of water masses with the open ocean, the Yangtze Sea developed anoxic, stagnant, low-energy bottom waters, especially within local depressions such as the Chuandong and Chuannan depocenters (Wang et al., 1993; Liang et al., 2009; Zou et al., 2018), which led to the organicrich shales of Longmaxi Formation being widely deposited in the Yangtze Platform, especially in the Chuandong and Chuannan depocenters (Figure 1C) (Guo et al., 2004; Mou et al., 2011). The black shale of the Longmaxi Formation varies from 20 to $100 \mathrm{~m}$ in thickness in the Sichuan Basin (Figure 1C).

The Lower Silurian Longmaxi Formation is divided into the Long1 Member and Long2 Member. The Long1 Member is further divided into Long11 sub-member (Long11) and Long12 sub-member (Long12) (Zou et al., 2015; Wang et al., 2020c). Long11 is mainly composed of black and gray-black carbonaceous and siliceous shale, which is the target section for shale gas exploration in the Sichuan Basin and surrounding areas. Long11 is further divided into four sections, named the Long11-1 section, Long11-2 section, Long11-3 section, and Long11-4 section (Wang et al., 2020a). The Long12 is mainly composed of dark gray shales and silty shales. The Long2 Member is mainly composed of gray argillaceous siltstones, silty mudstones, and siltstones. The lithology of the Longmaxi Formation generally shows a transition from black shale to siltstone from bottom to top (Figure 1B). Graptolites are the most common fossils in the Longmaxi Formation in the Sichuan Basin. Nine graptolite biozones were identified in the study sections, i.e., Persculptogr. Persculptus (LM1), Akidograptus ascensus (LM2), Parakidogr. Acuminatus (LM3), Cystograptus vesiculosus (LM4), Coronograptus cyphus (LM5), Demirastrites triangulates (LM6), Lituigraptus convolutes (LM7), Stimulograptus sedgawichii (LM8), and Spirograptus guerichi (LM9) (Chen et al., 2015). The Long11 sub-member corresponds to graptolite biozones of LM1-LM6.

\section{MATERIALS AND METHODS}

\section{Petrographic Observations}

The targeted research area is the Changning area in the southern Sichuan Basin with 81 core samples from the Longmaxi shale 


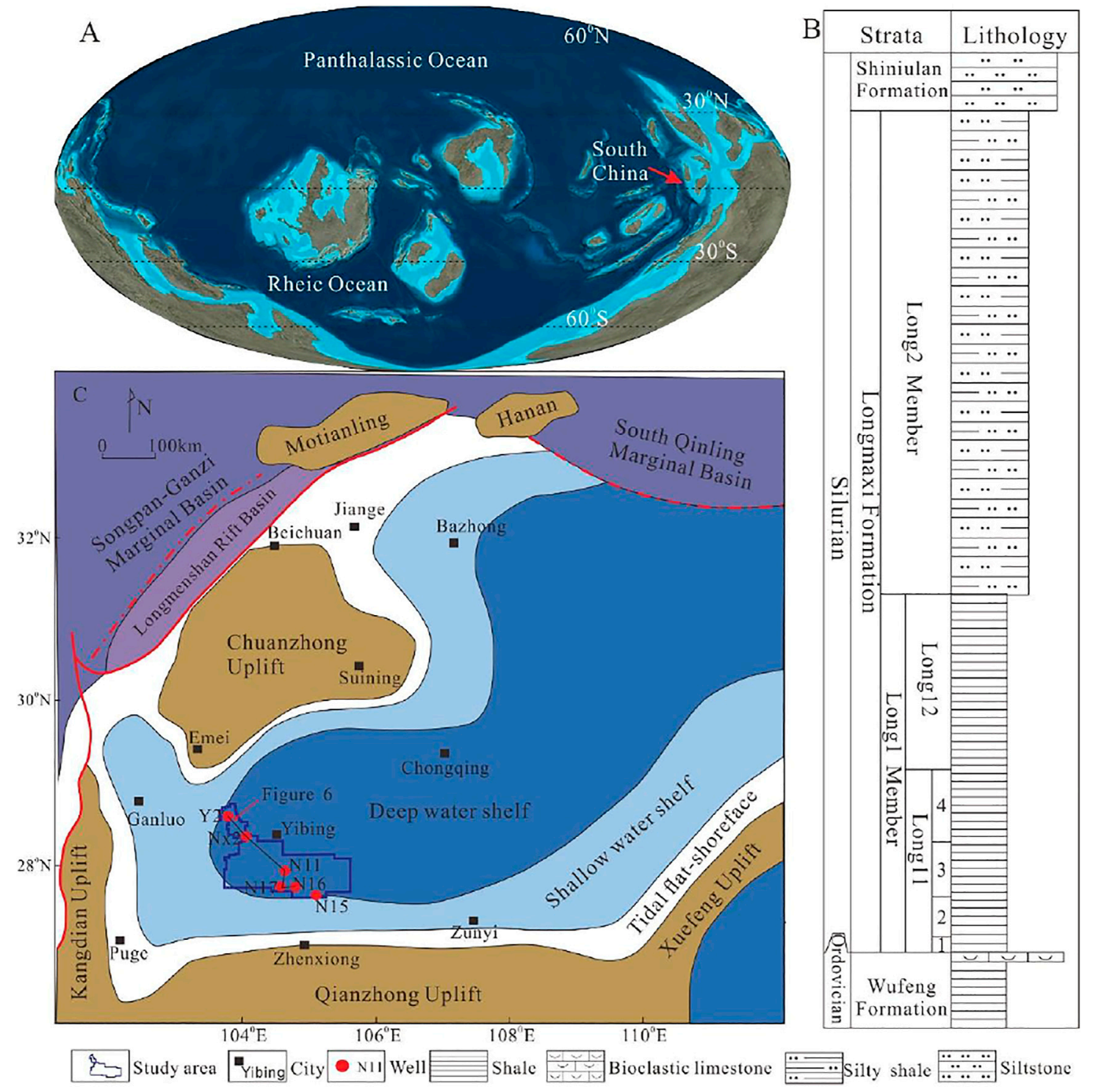

FIGURE 1 | (A) Global paleogeography during the Early Silurian (Yan et al., 2021). (B) Lithologic column of the Upper Wufeng Formation to the Lower Silurian Longmaxi Formation in the Changning area, south Sichuan Basin. (C) Paleogeographic map of the Yangtze area and location of the Changning area (modified from Huang et al., 2018; Chen et al., 2019; Yan et al., 2021).

collected from three wells (e.g. N11, N15, and Y2). Petrographic observations, including detailed core descriptions and thinsection observations, were conducted for this study.

\section{Geochemical Analyses}

Seven hundred ninety-two XRD data points for the Longmaxi shale from 10 wells were collected for use in this study. In addition, a total of 81 core samples were also collected from Wells N11, N15, and Y2 for geochemical analyses, including total organic carbon (TOC) content tests, XRD, major element tests, and trace element tests.

For the TOC measurements, all collected samples were leached with excess $\sim 20 \%$ hydrochloric acid to remove the carbonate phases and were washed in distilled water prior to analysis. The dried residues and non-acidified samples were measured with a LECO CS230 carbon sulfur analyzer at the Natural Gas Geology Key Laboratory of Sichuan Province at Southwest Petroleum University.

The major element and trace element tests and quantitative analysis of whole-rock minerals by using XRD were conducted at the State Key Laboratory Oil and Gas Reservoir Geology and Exploration at Southwest Petroleum University. For the major element and trace element measurements, dilithium tetraborate was used to melt the samples, ammonium nitrate was used as the oxidant, lithium oxide and a small amount of lithium bromide were used as the flux and mold release agent, an automatic fusion machine was used for fusion at a temperature range of $1,150^{\circ} \mathrm{C}-1,250^{\circ} \mathrm{C}$, glass sample wafers were made and 


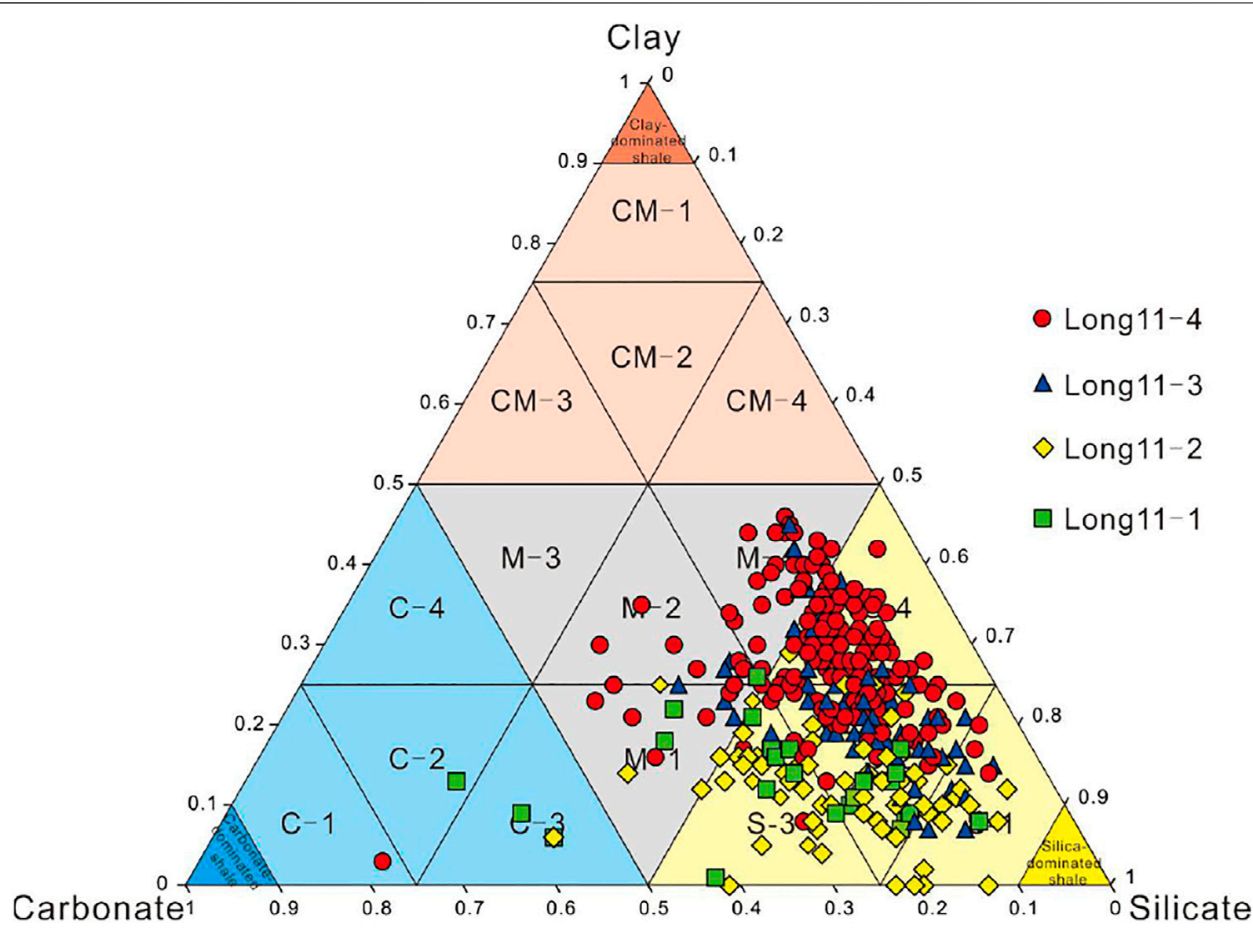

FIGURE 2 | Ternary plot showing the lithofacies types of the Longmaxi Formation in the Changning area (Ternary plot after Wu et al., 2016). M-1: carbonate/ siliceous shale, M-2: mixed shale, M-3: argillaceous/carbonate shale, M-4: argillaceous/siliceous shale, S-1: siliceous shale, S-2: mixed siliceous shale, S-3: carbonaterich siliceous shale, S-4: clay-rich siliceous shale, C-1: carbonate shale, C-2: mixed carbonate shale, C-3: silica-rich carbonate shale, C-4: clay-rich carbonate shale, CM1: argillaceous shale, CM-2: mixed argillaceous shale, CM-3: carbonate-rich argillaceous shale, CM-4: silica-rich argillaceous shale.

measured with an X-ray fluorescence spectrophotometer, and the contents of the major and trace elements were calculated separately according to their fluorescence intensities (Chen et al., 2019). In addition, a Rigaku SmartLab9 X-ray diffractometer was used for the quantitative analysis of wholerock minerals.

\section{Shale Lithofacies Classification}

The scheme for classifying the shale lithofacies follows the classification outlined by Gamero-Diaz et al. (2012) and modified by Wu et al. (2016). This classification scheme is determined by the XRD data. Figure 2 illustrates the shale lithofacies classification ternary diagram, which contains a total of four shale lithofacies associations and 16 shale lithofacies that are defined by three main components: silicate minerals (e.g., quartz + feldspar), carbonate minerals, and clay minerals (Wu et al., 2016). When the silica contents are greater than $50 \%$, this represents a siliceous shale association (S); when the carbonate mineral contents are greater than $50 \%$, this represents a carbonate shale association (C); and when the clay mineral contents are greater than $50 \%$, this represents a argillaceous shale association (CM). When the contents of the above three minerals are $25 \%-50 \%$, this represents a mixed shale association (M). Each lithofacies association is subdivided as follows: carbonate/siliceous shale (M-1), mixed shale (M-2), argillaceous/carbonate shale (M-3), argillaceous/siliceous shale (M-4), siliceous shale (S-1), mixed siliceous shale (S-2), carbonate-rich siliceous shale (S-3), clay-rich siliceous shale (S-4), carbonate shale (C-
1), mixed carbonate shale (C-2), silica-rich carbonate shale (C-3), clayrich carbonate shale (C-4), argillaceous shale (CM-1), mixed argillaceous shale (CM-2), carbonate-rich argillaceous shale (CM3 ), and silica-rich argillaceous shale (CM-4) (Figure 2).

\section{RESULTS}

\section{Shale Lithofacies Description}

Based on the shale lithofacies classification ternary diagram, we plotted the XRD data from 10 wells on the ternary diagram to classify the shale lithofacies. Seven main lithofacies were identified in the Changning area: siliceous shale (S-1), mixed siliceous shale (S-2), carbonate-rich siliceous shale (S-3), clay-rich siliceous shale ( $\mathrm{S}-4)$, carbonate/siliceous shale (M-1), mixed shale (M-2), and argillaceous/siliceous shale (M-4).

\section{Siliceous Shale (S-1)}

The siliceous shale (S-1) is mainly composed of silicate with contents of $75 \%-90 \%$, and the clay minerals and carbonate minerals content are both less than 25\% (Figure 2). This shale lithofacies is characterized by well-developed quartz lamination (detrital quartz), abundant quartz particles recrystallized from biogenic silica (Figures 3A, C), and abundant graptolites with the random arrangement (Figure 3B). This lithofacies is mainly developed in the Long11-1 section, Long11-2 section, and Long11-3 section in the Changning area. 

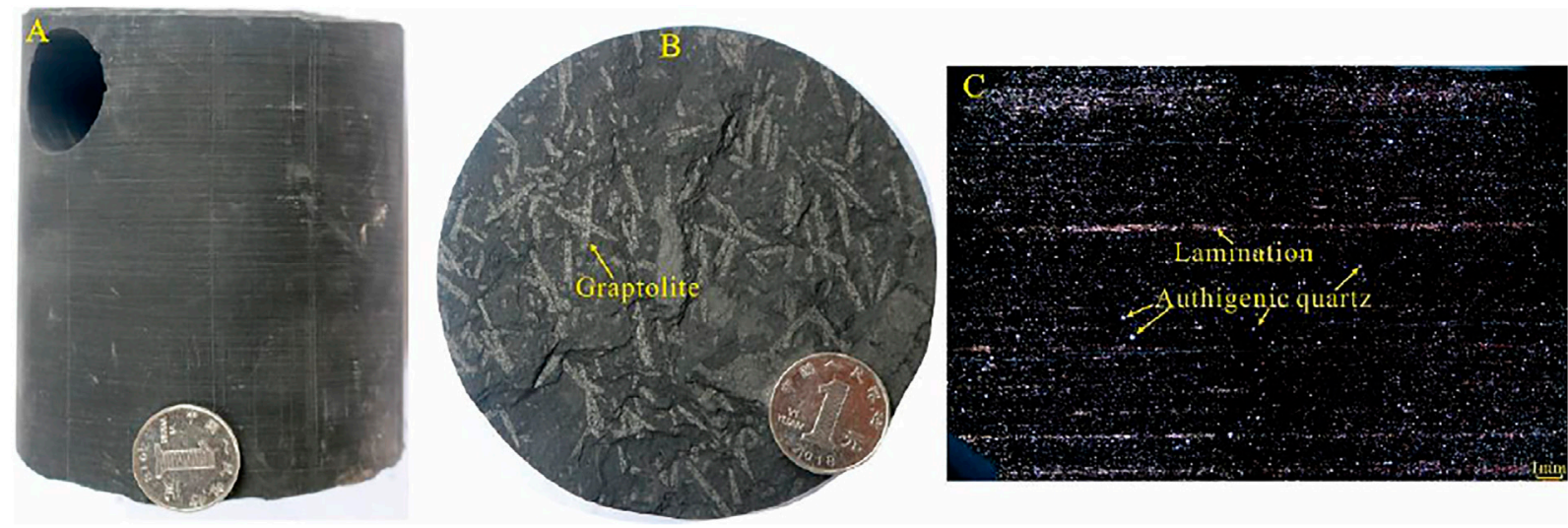

FIGURE 3 | Core photographs and thin-section photomicrograph showing characteristics of siliceous shale. (A) Core photograph showing lamination welldeveloped, 2,509.24-2,509.40 m, well N15. (B) Core photograph showing abundant graptolites with a random arrangement, 2,509.49-2,509.63 m, well N15. (C) Thinsection photomicrograph showing horizontal quartz lamination and abundant authigenic quartz particles developed, 2,507.09 m, well N15.

\section{Mixed Siliceous Shale (S-2)}

The mixed siliceous shale (S-2) is rich in silicate with contents ranging from $50 \%$ to $75 \%$, and poor in clay and carbonate minerals with contents both less than 25\% (Figure 2). This lithofacies is massive with quartz, dolomite, calcite, and a small amount of uniformly distributed flaky minerals (Figure 4D). Faint lamination can be occasionally observed in this lithofacies (Figure 4D). Most of the quartz particles are authigenic quartz that recrystallized from biogenic silica. Mixed siliceous shale (S-2) is the lithofacies type with the highest developmental frequency in the study area and is commonly developed in the Long11 sub-member, especially concentrated in the Long11-1 to Long11-3 sections.

\section{Carbonate-Rich Siliceous Shale (S-3)}

The carbonate-rich siliceous shale (S-3) is massive, poor in clay minerals $(<25 \%)$, rich in silicate $(50 \%-75 \%)$, and high in carbonate minerals (25\%-50\%) (Figure 2). When compared with mixed siliceous shale (S-2), the fractures are well developed and are filled by calcite in this lithofacies (Figure 4A). Carbonate-rich siliceous shale (S-3) is not common in the Longmaxi Formation and mainly developed at the bottom of the Longmaxi Formation, especially in the Long11-1 section.

\section{Clay-Rich Siliceous Shale (S-4)}

The clay-rich siliceous shale (S-4) exhibits high silicate contents $(50 \%-75 \%)$, moderate contents of clay minerals $(25 \%-50 \%)$, and low contents of carbonate minerals less than 25\% (Figure 2). Abundant lamination can be found (Figure 4E). Dolomite and calcite are sporadically distributed in this lithofacies (Figures $4 \mathrm{E}$, F). Clay-rich siliceous shale (S-4) is common in the Longmaxi Formation and is mainly concentrated in the Long11-3 section and Long11-4 section.

\section{Carbonate/Siliceous Shale (M-1)}

The carbonate/siliceous shale (M-1) is characterized by low contents of clay minerals $(<25 \%)$, moderate contents of carbonate minerals, and silicate $(25 \%-50 \%)$ (Figure 2). This lithofacies, which is characterized by well-developed horizontal lamination, occurs in the form of thin beds that are interbedded with other lithofacies (Figure 4B). Bentonite layers can be found in this lithofacies. Carbonate/siliceous shale (M-1) is not common in the Longmaxi Formation and is only developed at the top of the Long11 sub-member.

\section{Mixed Shale (M-2)}

The mixed shale (M-2) displays a massive structure with intricately distributed quartz, calcite, and clay minerals (Figures 4C, I). This lithofacies contains approximately equal amounts of silicate, clay, and carbonate minerals, which range from $25 \%$ to $50 \%$ (Figure 2). Mixed shale (M-2) shows a relatively higher development frequency in the Longmaxi Formation and mainly developed in the upper part of the Long11 sub-member in the form of thin beds.

\section{Argillaceous/Siliceous Shale (M-4)}

The argillaceous/siliceous shale (M-4) is poor in carbonate minerals with a content below $25 \%$. This lithofacies displays a massive structure with siltstone beds developed. The clay minerals and silicate contents both range from $25 \%$ to $50 \%$ in argillaceous/siliceous shale (M-4), which lead to the abundant quartz and clay minerals observed under the microscope (Figure 4G). Argillaceous/siliceous shale (M-4) is mainly developed in the upper part of the Long11 submember.

\section{Vertical Variations of Shale Lithofacies}

Vertically, the shale lithofacies exhibit a clear development pattern in the Long11 sub-member in the study area. The carbonate shale association + mixed shale association dominate the Long11-1 section. The siliceous shale association is mainly developed in Long11-2 section, Long11-3 section, and the lower part of Long11-4 section, and the mixed shale association + siliceous shale association is 

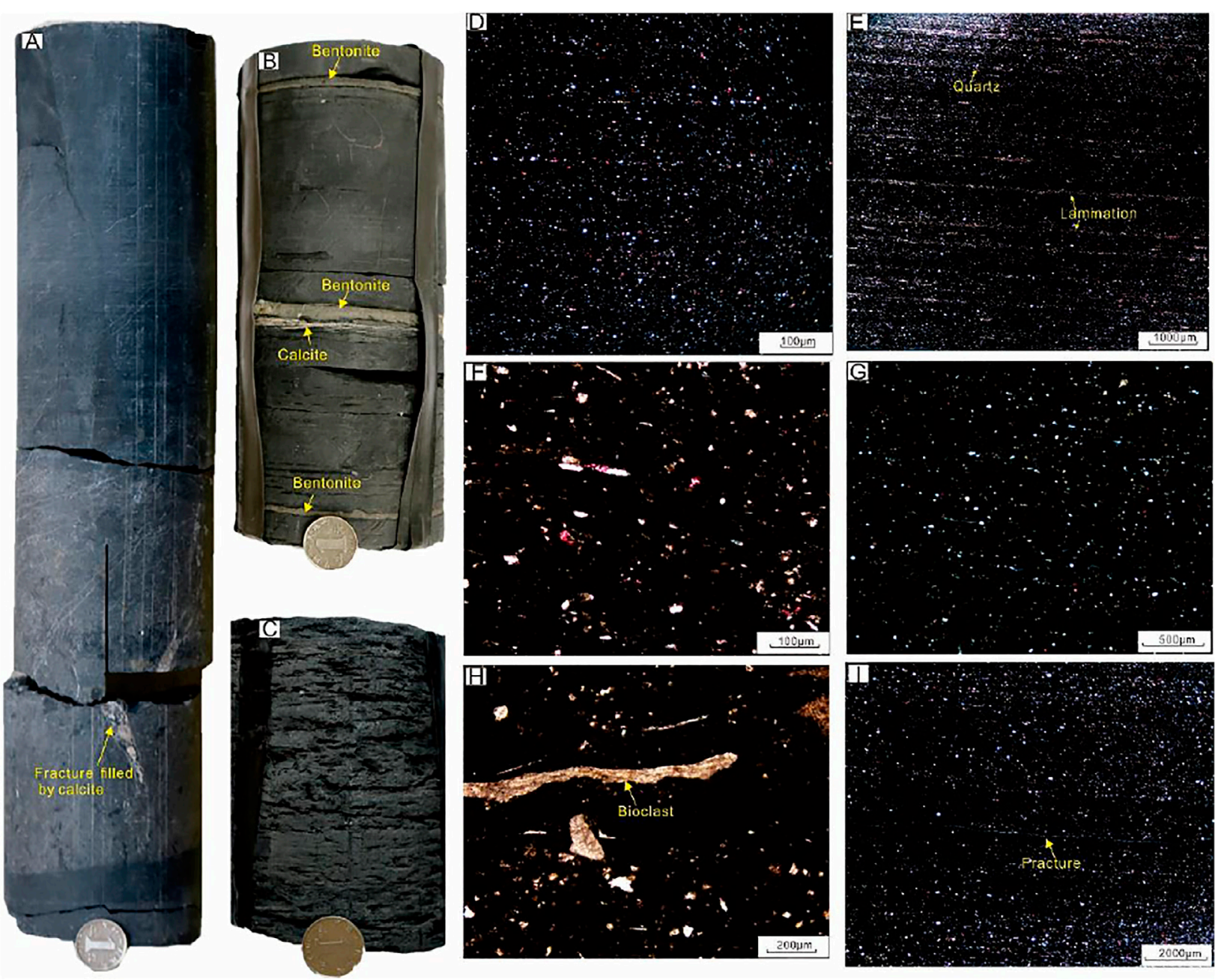

FIGURE 4 | Lithofacies types and characteristics of organic-rich shale in the Longmaxi Formation, Changning area. (A) Carbonate-rich siliceous shale (S-3), core photograph showing fractures filled by calcite, 2,232.78-2,232.24 m, well N10. (B) Carbonate/siliceous shale (M-1), core photograph showing bentonite and calcite lamination, 2,354.70-2,354.93 m, well N11. (C) Mixed shale (M-2), massive structure, 2,523.54-2,523.67 m, well N1. (D) Mixed siliceous shale (S-2), quartz, and calcite particles can be found in the thin section, 2,500.41 m, well N15. (E) Clay-rich siliceous shale (S-4), thin-section photo showing abundant parallel lamination,

2,508.68 m, well N15. (F) Clay-rich siliceous shale (S-4), thin-section photo showing quartz particles evenly distributed and micrite dolomite and calcite sporadically distributed, 2,493.98 m, well N15. (G) Argillaceous/siliceous shale (M-4), 2,486.5 m, well N15. (H) Carbonate/siliceous shale (M-1); bioclasts can be found in the thin section, 2,512.22 m, well N15. (I) Mixed shale (M-2) with microfractures found in the thin section, 2,491.59 m, well N15. Note that the diameter of the coin is $2.5 \mathrm{~cm}$.

mainly developed in the upper part of Long11-4 section (Figure 5). Figure 5 shows the vertical distributions of the shale lithofacies in the Long11 sub-member of well N15. Mixed carbonate shale (C-2) is mainly developed in the Long11-1 section and accounts for $70 \%$ of all developed lithofacies in this section. The siliceous shale association $(S)$ is dominant in the Long11-2 section, in which the mixed siliceous shale (S-2) accounts for more than $80 \%$ of all developed lithofacies in this section. Mixed siliceous shale (S-2) and argillaceous/siliceous shale (M-4) are the main lithofacies in the Long11-3 section, which account for $71 \%$ and $29 \%$, respectively. In the Long11-4 section, the siliceous shale association (S) is mainly developed in the lower part, and the mixed shale association $(\mathrm{M})$ is mainly developed in the upper part, which account for $53 \%$ and $47 \%$, respectively (Figure 5).

\section{Lateral Variations of Shale Lithofacies}

The west-east cross section (Well Y2-Well Nx2-Well N11-Well N17-Well N16) was used to analyze the lateral distribution characteristics of the shale lithofacies in the Long11 submember of the Longmaxi Formation in the Changning area. The results show that the lithofacies exhibit significant variations in their regional distributions (Figure 6). In the Long11-1 section, the shales are thicker in the west and thinner in the east. The western and eastern areas are dominated by mixed siliceous shale (S-2), while the middle part of the study area is mainly occupied by carbonate-rich siliceous shale (S-3). The shale thicknesses do not change much across the entire area in the Long11-2 section. The siliceous shale association (S) dominates the whole area in this section. From west to east, the shale lithofacies change from mixed siliceous shale (S-2) to siliceous shale (S-1) and then 


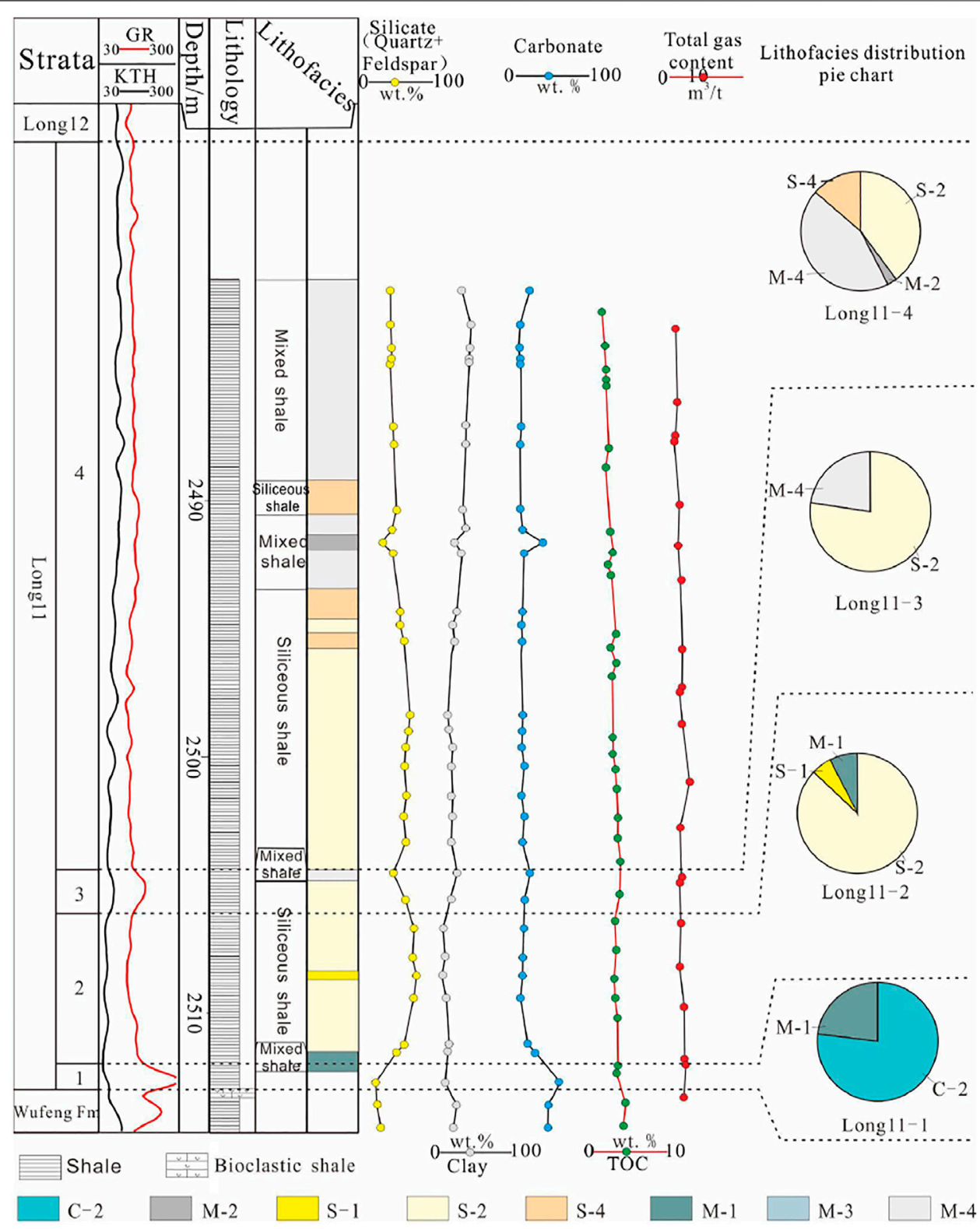

FIGURE $\mathbf{5}$ | Vertical variation sequence of the shale lithofacies of the Longmaxi Formation in Well N15 in the Changning area.

change to carbonate-rich siliceous shale (S-3). The shale thicknesses do not vary significantly across the whole area in the Long11-3 section. The shale lithofacies gradually change from a siliceous shale association (S) to siliceous shale association $(\mathrm{S})+$ mixed shale association (M) from west to east. Mixed siliceous shale (S-2) and clay-rich siliceous shale (S-4) dominate the western area and then change to siliceous shale (S-1) in the middle and change to clay-rich siliceous shale (C-1) interbedded with clay-rich siliceous shale (S-4) in well N17. In the east, it is dominated by mixed siliceous shale (S-2) and clay-rich siliceous shale (S-4) in the Long11-3 section. The shale thicknesses exhibit a thinning trend from west to east in the Long11-4 section. Clayrich siliceous shale (S-4) dominates the whole area except for carbonate/siliceous shale (M-1) and argillaceous/siliceous shale (M-4), which are well developed in the west (Figure 6).

\section{Spatial Distributions of Shale Lithofacies}

The spatial distribution of the shale lithofacies shows obvious variations in different sections of the Long11 sub-member (Figure 7). During the period of the Long11-1 section, mixed siliceous shale (S-2) dominated most areas of the Changning area, except that carbonate-rich siliceous shale (S-3) occupied the east area and carbonate/siliceous shale (M-1) were concentrated in the middle area (Figure 7A). During the period of the Long11-2 section, siliceous shale association (S) was developed in the whole area. Mixed siliceous shale 


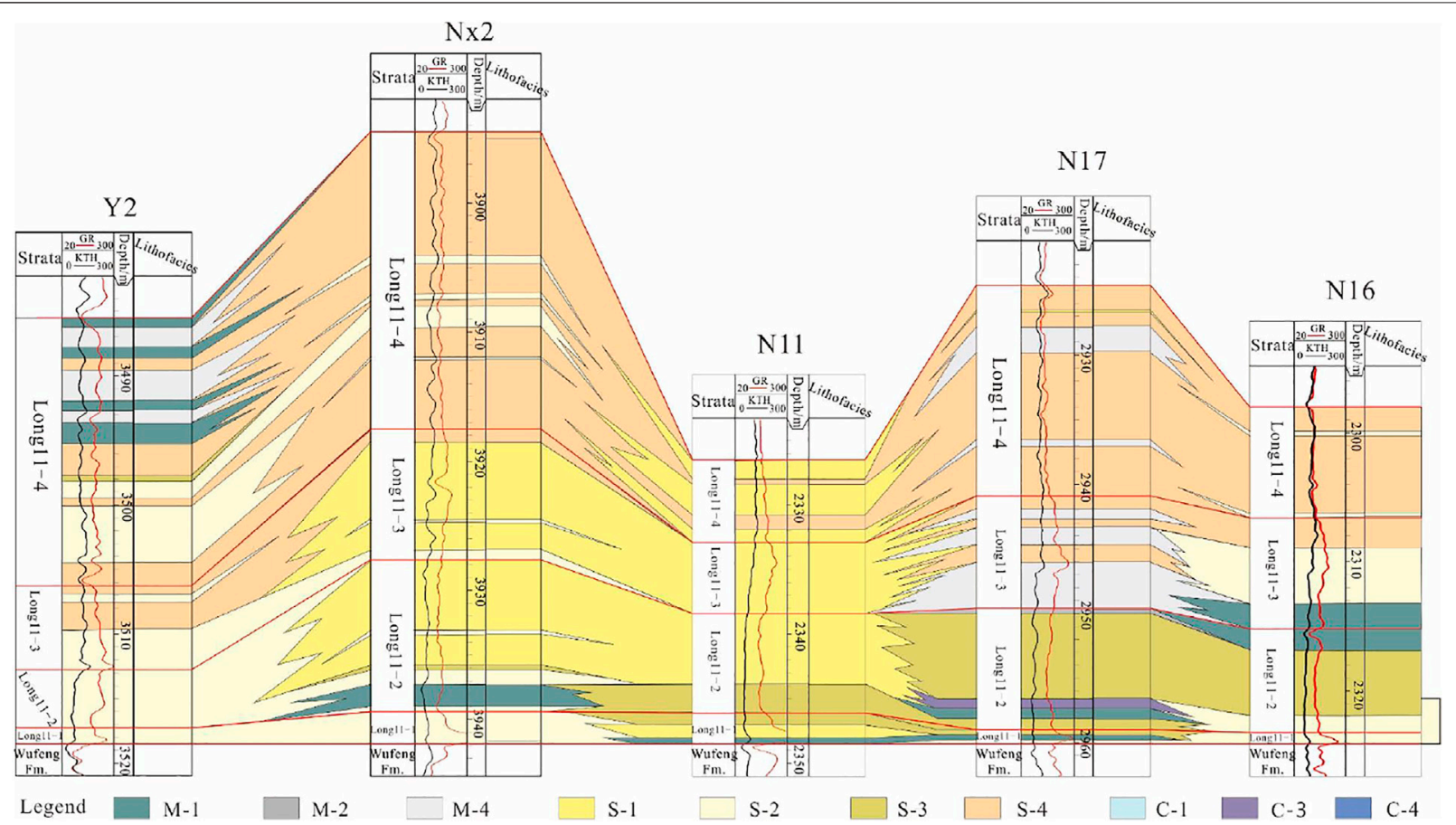

FIGURE 6 | Cross section of wells Y2-NX2-N11-N17-N16 showing the lateral distribution characteristics of the shale lithofacies of the Longmaxi Formation in the Changning area.

(S-2) occupied the most area. Siliceous shale (S-1) was developed in the northwest area, and carbonate-rich siliceous shale (S-3) was widely distributed in the east area (Figure 7B). During the period of the Long11-3 section, the whole area was dominated by mixed siliceous shale (S-2) with siliceous shale (S-1) locally developed in the northwest and by argillaceous/siliceous shale (M-4) that developed in the middle area (Figure 7C). During the period of the Long11-4 section, clay-rich siliceous shale (S-4) and mixed siliceous shale (S-2) occupied the whole area (Figure 7D).

\section{DISCUSSION}

\section{Main Controlling Factors of Spatial and Temporal Variations in Shale Lithofacies}

Previous research has focused on the main controlling factors of how shale lithofacies formed in the Longmaxi Formation in the Sichuan Basin and its surrounding areas (Zhao et al., 2016a; Tang et al., 2016; Wang et al., 2016; Wu et al., 2016; Lu et al., 2017; Liu et al., 2018; Wang et al., 2020b; Wang et al., 2021b). It is generally believed that volcanic activities, terrigenous supplies, sea-level changes, and redox conditions played an important role in controlling the development of the shale lithofacies types (Zhao et al., 2016a; Wang et al., 2018). However, the main controlling factors of the spatial and temporal distributions of the shale lithofacies were not involved in previous studies. This section focuses on the main geological factors that controlled the spatial and temporal distributions of the shale lithofacies in the Longmaxi Formation in the Changning area.

\section{Paleogeomorphology}

To study how the paleogeomorphology controlled the shale lithofacies distributions, we compared the shale lithofacies in different paleogeomorphology units during the period of the Long11-1 section and Long11-2 section.

During the period of the Long11-1 section, the relatively high geomorphic area, which was located in the area of Well Y1 in the west, was dominated by mixed siliceous shale (S-2). The lowlying areas, which were located in the middle of the research area, were dominated by mixed siliceous shale (S-2) and carbonate/siliceous shale (M-1). The geomorphic highland in the east was dominated by carbonate-rich siliceous shale (S-3) and mixed siliceous shale (S-2) (Figure 8). During the period of the Long11-2 section, the relatively high geomorphic area in the west was dominated by siliceous shale $(\mathrm{S}-1)$ and mixed siliceous shale (S-2); the low-lying areas in the middle were dominated by mixed siliceous shale (S-2), and the geomorphic highland in the east was dominated by carbonate-rich siliceous shale (S-3) and mixed siliceous shale (S-2) (Figure 9). It is obvious that the shale lithofacies in the geomorphic highlands had high silicate contents, while these were low in the low-lying areas. According to previous research, the silica in the shales of the Longmaxi Formation mainly were derived from silica radiolarians, which mainly live in deep-water areas (Zhao et al., 2016b; Lu et al., 2018; Yang et al., 2018; Dong et al., 2019; Li et al., 2019; Liu et al., 2019; Yang et al., 2019; Liang et al., 

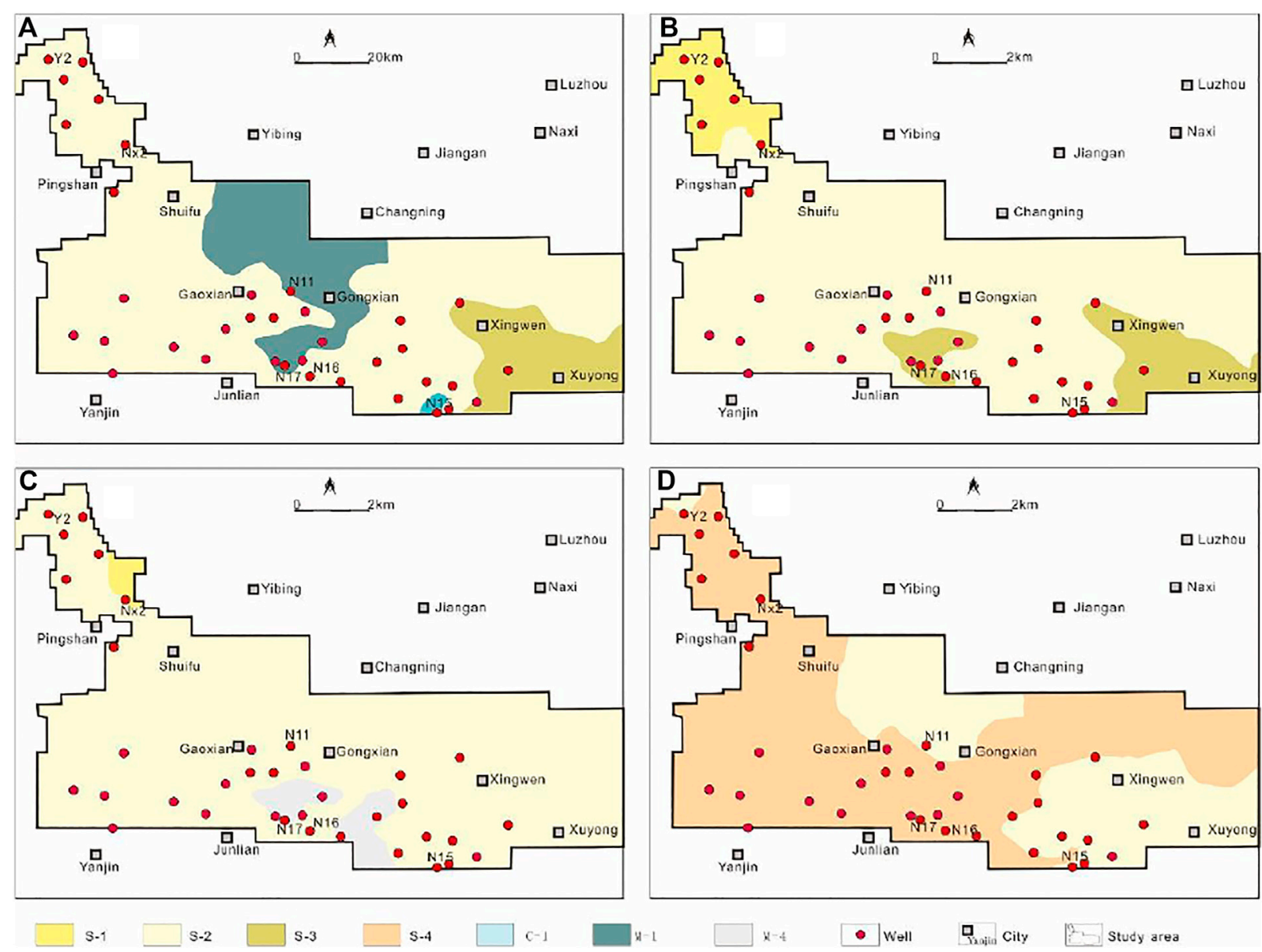

FIGURE 7 | Spatial distribution characteristics of shale lithofacies in different sections of the Longmaxi Formation in the Changning area. (A) Lithofacies distribution of the Long11-1 section. (B) Lithofacies distribution of the Long11-2 section. (C) Lithofacies distribution of the Long11-3 section. (D) Lithofacies distribution of the Long11-4 section.

2020; Guan et al., 2021; Xu et al., 2021). According to this conclusion, the shale lithofacies should be rich in siliceous content in the depressions (low-lying areas) but be lacking siliceous content in geomorphic highlands. However, the results of this research are obviously contrary. This result indicates that there may have been multiple silica sources in the shales of the Longmaxi Formation in the research area. The paleogeomorphology has a certain controlling effect on the distribution of the shale lithofacies. The control by the paleogeomorphology on the shale lithofacies may be related to the provenance system. The southeast and northwest areas are close to the provenance (Rong et al., 2003; Wang et al., 2020c). This led to large amounts of terrigenous siliceous materials coming from these two provenances, which formed high-silica shale together with biological silicon in the geomorphic highlands in the western and eastern areas. However, due to the small terrigenous influence, the contents of carbonate minerals and clay minerals increased in the low-lying areas, which eventually led to the development of shale lithofacies with relatively higher content of carbonate and clay minerals.

\section{Relative Sea-Level Change}

Surrounded by the Qianzhong Uplift, Chuanzhong Uplift, and Xuefeng Uplift, a semi-restricted sedimentary environment was formed and occupied most areas of the Sichuan Basin during the period of the Longmaxi Formation (He et al., 2019). Sea level changes directly affected the degrees of restriction and retention of the water mass and further controlled the development of the shale lithofacies. The Mo-TOC covariant relationship can effectively indicate the degree of restriction of a water mass in a sedimentary environment (Algeo and Lyons, 2006). Shales with high TOC and low Mo contents are easily deposited in restricted environments, while those deposited in open environments are generally characterized by low TOC and high Mo contents (Algeo and Lyons, 2006). The Mo-TOC covariant relationship in the Longmaxi shale shows that the degree of restriction of the sedimentary environment gradually improved from the Long11-1 section to the Long11-4 section in the Changning area (Figure 10). Shale samples with TOC greater than $2 \%$ and less than $4 \%$ are distributed in weakly restricted and moderately restricted environments, while nearly all shale samples with TOC greater 


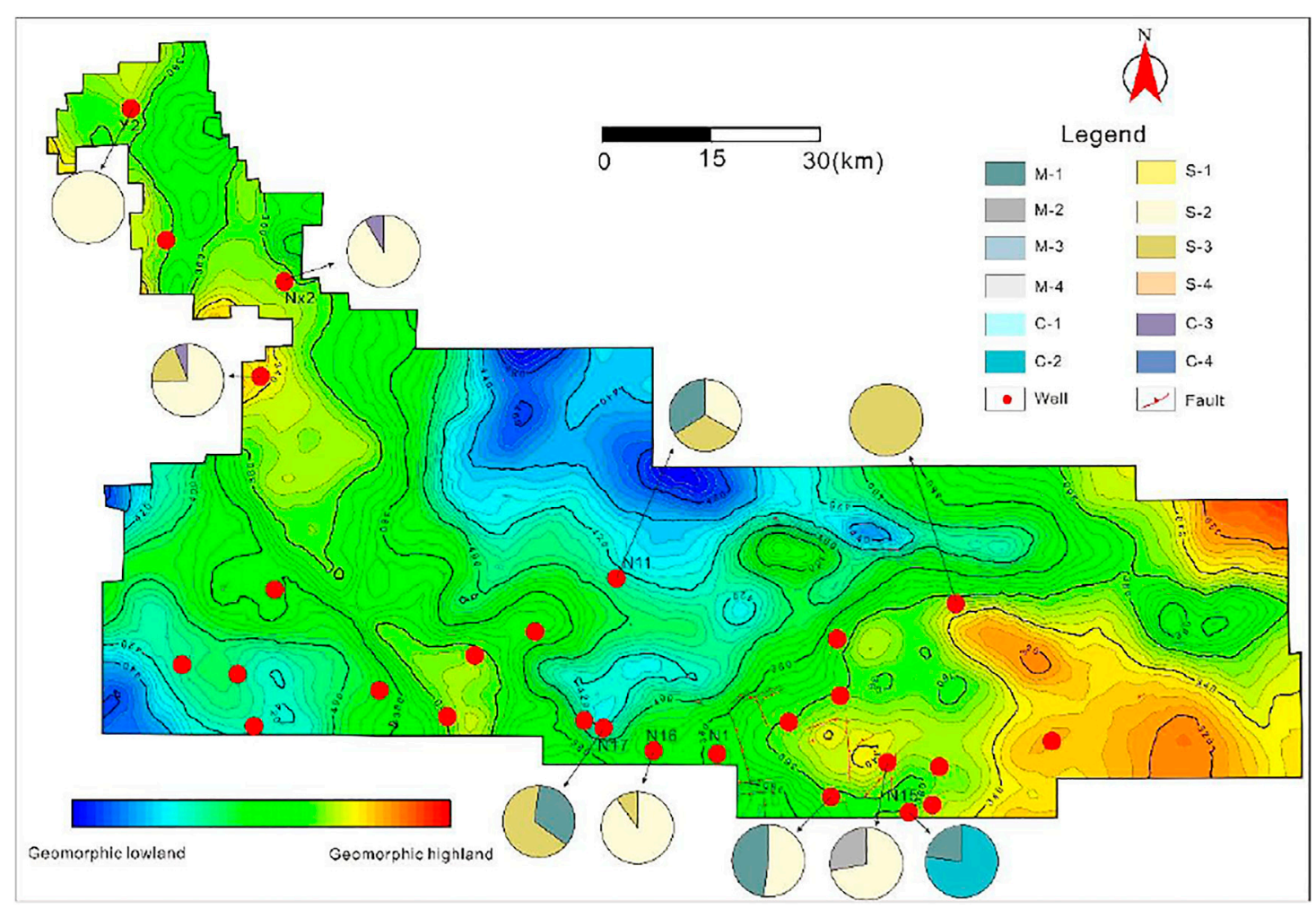

FIGURE 8 | Lithofacies proportions of the Long11-1 section in different geomorphic units in the Changning area.

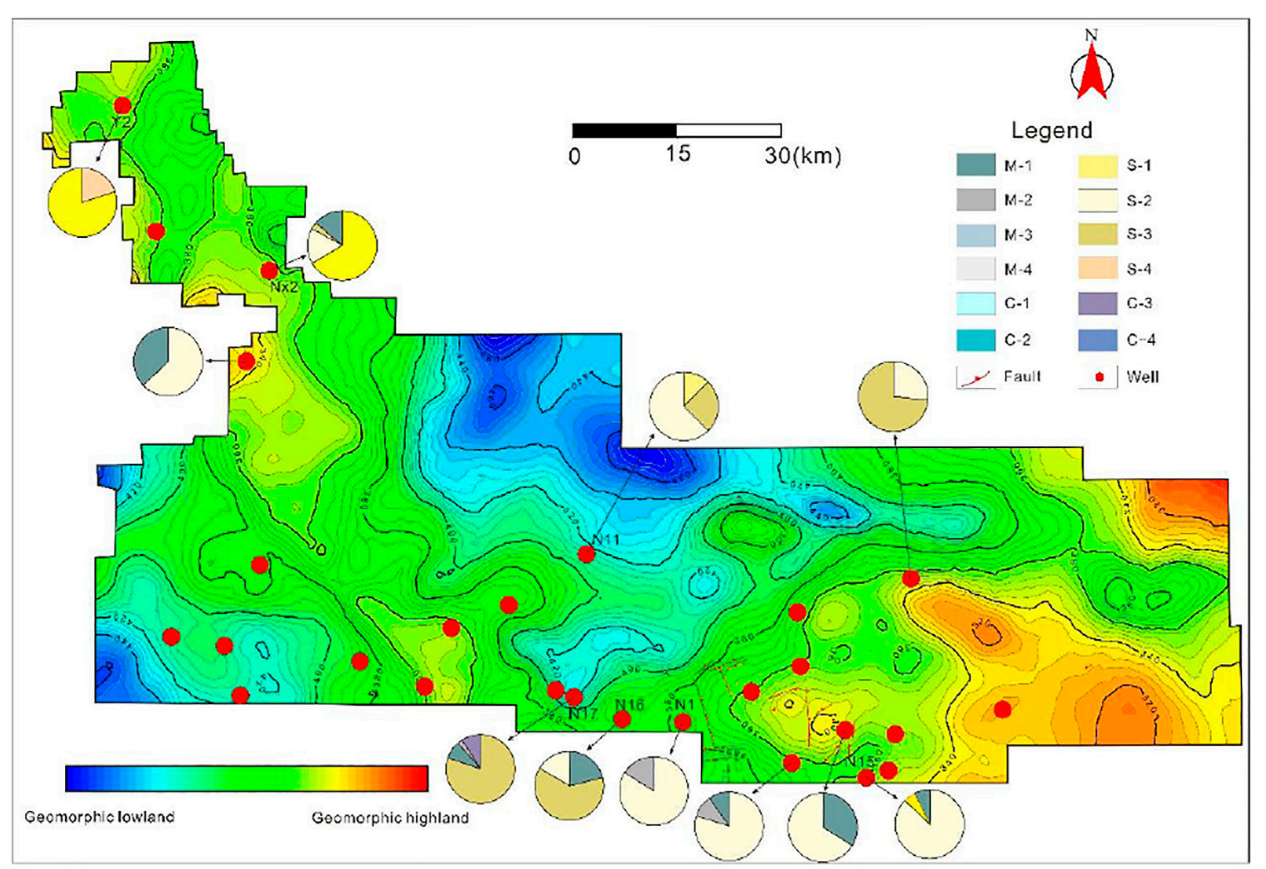

FIGURE 9 | Lithofacies proportions of the Long11-2 section in different geomorphic units in the Changning area. 


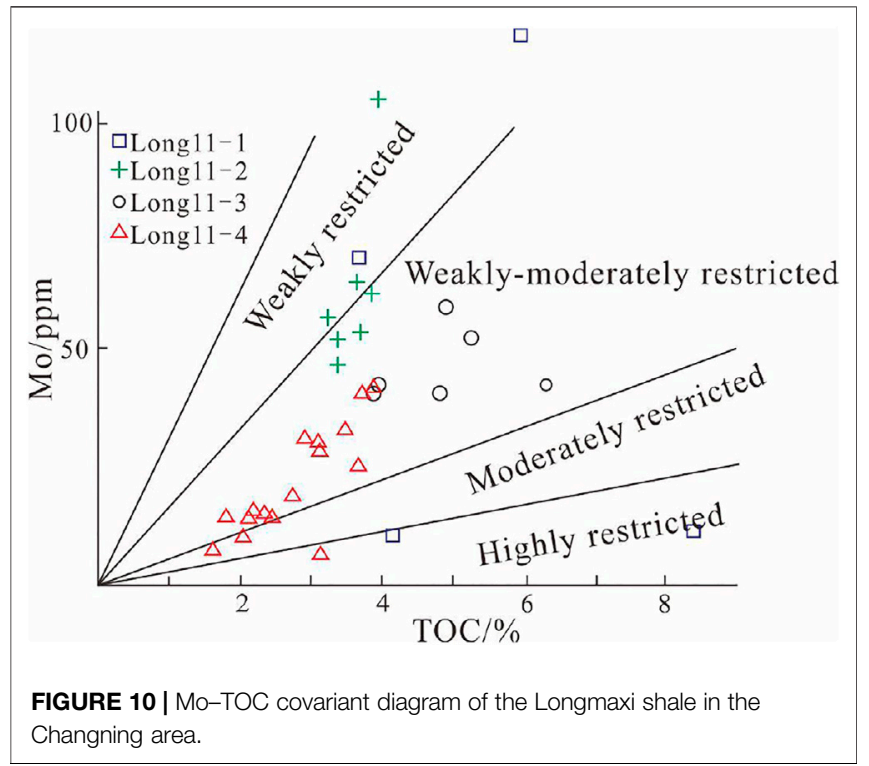

than $4 \%$ are concentrated in weakly to weakly-moderately restricted environments (Figure 10). The Long11-1 to Long11-3 sections display relatively higher Mo contents, which reach an average value of $63.72 \mathrm{ppm}$, while the Mo contents of the Long11-4 section are relatively lower with an average value of $20.33 \mathrm{ppm}$.

After the Hirnantian Ice Age, the climate warmed and the ice melted in the Early Silurian, which resulted in a large-scale transgression happening in the Upper Yangtze Platform, so the sedimentary environment rapidly transformed into an anoxic stagnant basin during the period of the Long1 Member. Transgression occurred during the time of the Long11-1 section and Long11-2 section, with sea level rising rapidly in the Changning area (Figure 11), which led to an improvement in the restriction degree. However, the sedimentary environment gradually changed from a carbonate platform to shelf environment from the period of the Guanyinqiao section of the Upper Ordovician Wufeng Formation to the period of the Long11-1 section. Therefore, lithofacies rich in carbonate (e.g., carbonate-rich siliceous shale and carbonate/ siliceous shales) were widely distributed in the research area during the period of the Long11-1 section and then changed to mixed siliceous shale (S-2) and siliceous shale (S-1) during the period of the Long11-2 section. During the period of the Long11-3 section, the sea level was relatively higher (Figure 11), and the restricted degree of the water mass was further improved, which caused the shale lithofacies to be more stable than that of the Long11-2 section. Mixed siliceous shale (S-2) dominated the study area during the Long11-3 section. Sea levels began to fall during the period of the Long11-4 section (Figure 11), which caused the terrestrial inputs to increase, and resulted in the domination of mixed siliceous shale (S-2) + argillaceous/siliceous shale (M-4) in the Long11-4 section compared with the Long11-3 section.

\section{Sedimentary Model of Shale Lithofacies Evolution}

The paleogeomorphology exhibits depressions (low-lying areas) and geomorphic highlands that developed during the period of the

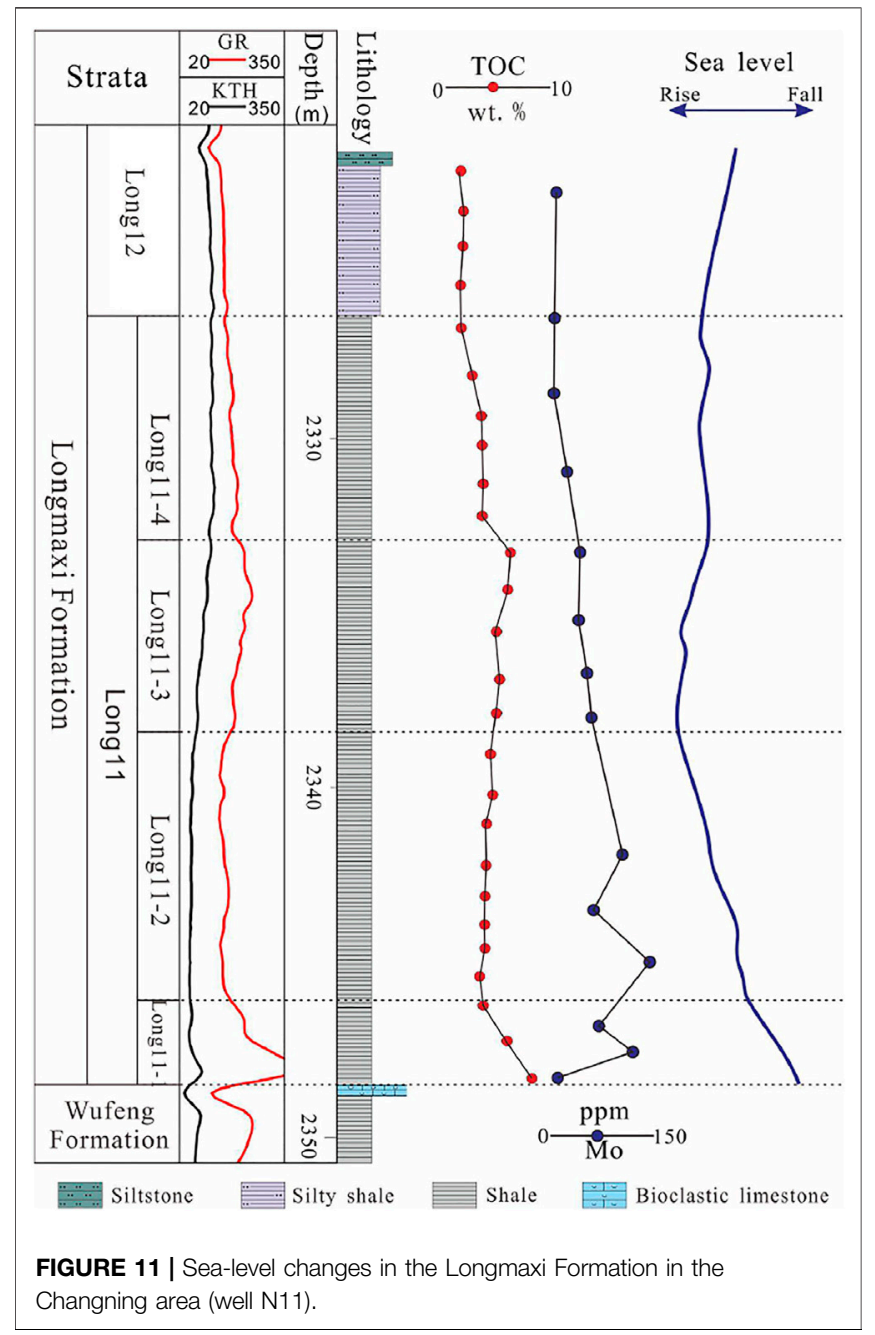

Longmaxi Formation in the study area. The geomorphic highland areas were located in the west and east. The depression (low-lying area) was located in the middle of the study area. After the Gondwana Glaciation in the Hirnantian (Late Ordovician), temperatures began to rise and glaciers began to melt, leading to a large-scale transgression occurring during the Early Silurian on the Upper Yangtze Platform, which resulted in the sedimentary environment changing to a restricted anoxic environment (Brenchley et al., 2001; Yan et al., 2021; Chen et al., 2015b; Chen et al., 2021; Wei et al., 2021). During the period of the Long11-1 section, the transgression began with relatively low sea levels, and the sedimentary water mass was weakly restricted (Yan et al., 2021). The siliceous shale association $(S)+$ mixed shale association $(M)$ were mainly developed during this period. Mixed siliceous shale (S-2) and carbonate-rich siliceous shale (S-3) were mainly distributed in the geomorphic highland areas, and the carbonate/siliceous shale (M-1) was mainly developed in the depression (low-lying area) in the middle of the study area during the period of the Long11-1 section. As the transgression continued and sea levels rose, the sedimentary environment became weakly restricted-moderately restricted during the period of the Long11-2 section. The siliceous shale association (S) dominated the study area, with siliceous shale (S-1) mainly 

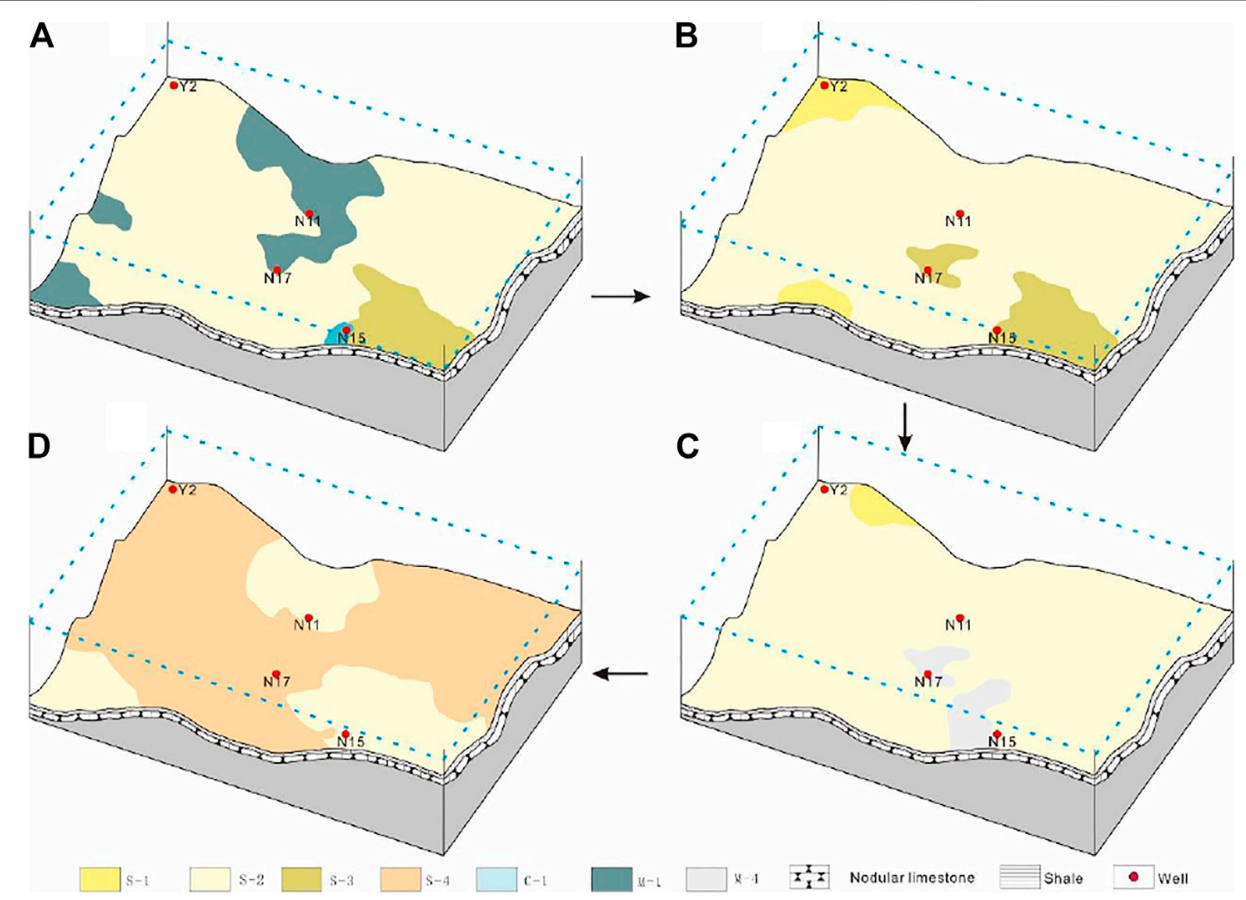

FIGURE 12 | Shale lithofacies evolution model of the Longmaxi Formation in the Changning area.

distributed in the geomorphic highland areas in the west, carbonaterich siliceous shale (S-3) developed in the geomorphic highland areas in the east (higher carbonate content), and mixed siliceous shale (S2) developed in the depression (low-lying area) in the middle area. During the period of the Long11-3 section, the transgression reached its peak and resulted in a moderately restricted sedimentary environment that dominated the study area. The mixed siliceous shale (S-2) occupied the largest area, with siliceous shales (S-1) distributed sporadically in the geomorphic highland area in the west, and argillaceous/carbonate shales (M-3) developed in the depression (low-lying area) in the middle area. During the early stage of the Long11-4 section, the sedimentary environment was still moderately restricted in the research area. Regression occurred at the late stage of the Long11-4 section. The whole area was dominated by clay-rich siliceous shale (S-4), except that the eastern and middle areas were mainly dominated by mixed siliceous shale (S-2) (Figure 12).

\section{CONCLUSION}

1) Seven main shale lithofacies were identified in the Long11 sub-member of the Longmaxi Formation in the Changning area, i.e., siliceous shale (S-1), mixed siliceous shale (S-2), carbonate-rich siliceous shale (S-3), clay-rich siliceous shale (S-4), carbonate/siliceous shale (M-1), mixed shale (M-2), and argillaceous/siliceous shale (M-4).

2) Vertically, the carbonate shale association + mixed shale association, siliceous shale association, and mixed shale association + siliceous shale association are developed from the bottom to top of the Long11 sub-member of the
Longmaxi Formation in the Changning area. The spatial distribution of the shale lithofacies shows clear variations in the Long11 sub-member. Compared to the shale lithofacies in the central area, the shale lithofacies changes rapidly in the eastern and western parts of the study area. The lithofacies are rich in silicate in the eastern and western areas while rich in carbonate and clay in the middle area.

3) The spatial and temporal distributions of the shale lithofacies are mainly controlled by paleogeomorphology and relative sea-level changes. The geomorphic highland area is dominated by siliceous shale associations, e.g., siliceous shale (S-1), mixed siliceous shale (S-2), and carbonate-rich siliceous shale (S-3). The depression (low-lying area) is mainly dominated by carbonate/siliceous shale (M-1) and mixed siliceous shale (S2) in the Changning area.

\section{DATA AVAILABILITY STATEMENT}

The raw data supporting the conclusions of this article will be made available by the authors without undue reservation.

\section{AUTHOR CONTRIBUTIONS}

QT contributed as the major author of the article. LZ and LC conceived the project. XT collected the samples. GW analyzed the samples. All authors contributed to the article and approved the submitted version. 


\section{FUNDING}

This study was jointly funded by the National Natural Science Foundation of China (Grant No. 41602147) and Science and Technology Cooperation Project of the CNPC-SWPU Innovation Alliance (Grant No. 2020CX020000).

\section{REFERENCES}

Algeo, T. J., and Lyons, T. W. (2006). Mo-total Organic Carbon Covariation in Modern Anoxic marine Environments: Implications for Analysis of Paleoredox and Paleohydrographic Conditions. Paleoceanography 21, a-n. doi:10.1029/ 2004PA001112

Brenchley, P. J., Marshall, J. D., and Underwood, C. J. (2001). Do All Mass Extinctions Represent an Ecological Crisis? Evidence from the Late Ordovician. Geol. J. 36, 329-340. doi:10.1002/gj.880.abs

Bruner, K. R., Walker-Milani, M., and Smosna, R. (2015). Lithofacies of the Devonian Marcellus Shale in the Eastern Appalachian basin, U.S.A. J. Sediment. Res. 85, 937-954. doi:10.2110/jsr.2015.62

Buntoro, A., Prasetyadi, C., Wibowo, R. A., Suranto, J. D., Cahyadi, T. A., Muangthai, I., et al. (2020). Sweet Spot Fracable Window of Lithofacies Association of Brown Shales in KiliranJao Sub-basin, West Sumatra Indonesia Using Rock Geomechanics Approach. AIP Conf. P. 2245, 1-8. doi:10.1063/5.0007212

Chen, L., Jiang, S., Chen, P., Chen, X., Zhang, B., Zhang, G., et al. (2021). Relative Sea-Level Changes and Organic Matter Enrichment in the Upper Ordovician-Lower Silurian Wufeng-Longmaxi Formations in the Central Yangtze Area, China. Mar. Pet. Geology. 124, 104809. doi:10.1016/ j.marpetgeo.2020.104809

Chen, L., Lu, Y., Jiang, S., Li, J., Guo, T., and Luo, C. (2015a). Heterogeneity of the Lower Silurian Longmaxi marine Shale in the Southeast Sichuan Basin of China. Mar. Pet. Geology. 65, 232-246. doi:10.1016/j.marpetgeo.2015.04.003

Chen, L., Lu, Y., Li, J., Guo, X., Jiang, S., and Luo, C. (2020). Comparative Study on the Lower Silurian Longmaxi marine Shale in the Jiaoshiba Shale Gas Field and the Pengshui Area in the Southeast Sichuan Basin, China. Geosci. J. 24, 61-71. doi:10.1007/s12303-019-0014-y

Chen, L., Wang, G., Yang, Y., Jing, C., Chen, M., and Tan, X. (2019). Geochemical Characteristics of Bentonite and its Influence on Shale Reservoir Quality in Wufeng-Longmaxi Formation, South Sichuan Basin, China. Energy Fuels 33, 12366-12373. doi:10.1021/acs.energyfuels.9b03510

Chen, X., Fan, J. X., Zhang, Y. D., Wang, H. Y., Chen, Q., Wang, W. H., et al. (2015b). Subdivision and Delineation of the Wufeng and Lungmachi Black Shales in the Subsurface Areas of the Yangtze Platform. J. Stratigr. 39 (4), 351-358.

Dai, J., Zou, C., Liao, S., Dong, D., Ni, Y., Huang, J., et al. (2014). Geochemistry of the Extremely High thermal Maturity Longmaxi Shale Gas, Southern Sichuan Basin. Org. Geochem. 74, 3-12. doi:10.1016/j.orggeochem.2014.01.018

Dong, D., Gao, S., Huang, J., Guan, Q., Wang, S., and Wang, Y. (2015a). Discussion on the Exploration \& Development prospect of Shale Gas in the Sichuan Basin. Nat. Gas Industry B 2, 9-23. doi:10.1016/j.ngib.2015.02.002

Dong, D., Shi, Z., Guan, Q., Jiang, S., Zhang, M., Zhang, C., et al. (2018). Progress, Challenges and Prospects of Shale Gas Exploration in the Wufeng-Longmaxi Reservoirs in the Sichuan Basin. Nat. Gas Industry B 5, 415-424. doi:10.1016/ j.ngib.2018.04.011

Dong, D., Zou, C., Dai, J., Huang, S., Zheng, J., Gong, J., et al. (2016). Suggestions on the Development Strategy of Shale Gas in China. J. Nat. Gas Geosci. 1, 413-423. doi:10.1016/j.jnggs.2016.11.011

Dong, T., Harris, N. B., Ayranci, K., Twemlow, C. E., and Nassichuk, B. R. (2015b). Porosity Characteristics of the Devonian Horn River Shale, Canada: Insights from Lithofacies Classification and Shale Composition. Int. J. Coal Geology. 141-142, 14174-14290. doi:10.1016/j.coal.2015.03.001

Dong, T., He, S., Chen, M., Hou, Y., Guo, X., Wei, C., et al. (2019). Quartz Types and Origins in the Paleozoic Wufeng-Longmaxi Formations, Eastern Sichuan Basin, China: Implications for Porosity Preservation in Shale Reservoirs. Mar. Pet. Geology. 106, 62-73. doi:10.1016/j.marpetgeo.2019.05.002

\section{ACKNOWLEDGMENTS}

We are warmly grateful to Xin Chen, Chang $\mathrm{Lu}$, and Yue $\mathrm{Hu}$ for their earlier work about the thin-section analysis and core study. We are also grateful to two reviewers and handling editor for their critical comments and constructive suggestions.

Du, X.-B., Zhang, M.-Q., Lu, Y.-C., Ping, C., and Lu, Y.-B. (2015). Lithofacies and Depositional Characteristics of Gas Shales in the Western Area of the Lower Yangtze, China. Geol. J. 50, 683-701. doi:10.1002/gj.2587

Feng, Z., Hao, F., Zhou, S., Wu, W., Tian, J., Xie, C., et al. (2020). Pore Characteristics and Methane Adsorption Capacity of Different Lithofacies of the Wufeng Formation-Longmaxi Formation Shales, Southern Sichuan Basin. Energy Fuels 34, 8046-8062. doi:10.1021/acs.energyfuels.0c00782

Gamero-Diaz, H., Miller, C., and Lewis, R. (2012). sCore: A Classification Scheme for Organic Mudstones Based on Bulk Mineralogy. New Orleans, Louisiana, United States: Search and Discovery, 40951.

Gou, Q., Xu, S., Hao, F., Yang, F., Zhang, B., Shu, Z., et al. (2019). Full-scale Pores and Micro-fractures Characterization Using FE-SEM, Gas Adsorption, NanoCT and micro-CT: A Case Study of the Silurian Longmaxi Formation Shale in the Fuling Area, Sichuan Basin, China. Fuel 253, 167-179. doi:10.1016/ j.fuel.2019.04.116

Gou, Q., Xu, S., Hao, F., Zhang, B., Shu, Z., Yang, F., et al. (2020). Quantitative Calculated Shale Gas Contents with Different Lithofacies: A Case Study of Fuling Gas Shale, Sichuan Basin, China. J. Nat. Gas Sci. Eng. 76, 103222. doi:10.1016/j.jngse.2020.103222

Guan, Q., Dong, D., Zhang, H., Sun, S., Zhang, S., and Guo, W. (2021). Types of Biogenic Quartz and its Coupling Storage Mechanism in Organic-Rich Shales: A Case Study of the Upper Ordovician Wufeng Formation to Lower Silurian Longmaxi Formation in the Sichuan Basin, SW China. Pet. Exploration Dev. 48 (4), 813-823. doi:10.1016/S1876-3804(21)60068-X

Guo, T. L., and Zhang, H. R. (2014). Formation and Enrichment Mode of Jiaoshiba Shale Gas Field, Sichuan basin. Petrol. Explor. Dev. 41, 28-36. doi:10.1016/ s1876-3804(14)60003-3

Guo, Y. H., Li, Z. F., Li, T. F., Zhang, T. M., Wang, Z. C., Yu, J. F., et al. (2004). Lithofacies Palaeogeography of the Early Silurian in Sichuan Area. J. Palaeogeogr. 6, 20-29.

He, L., Wang, Y. P., and Chen, D. F. (2019). Geochemical Features of Sedimentary Environment and Paleoclimate during Late Ordovician to Early Silurian in Southern Sichuan Basin. Geochimica 48, 555-566. doi:10.19700/ j.0379-1726.2019.06.004

Hickey, J. J., and Henk, B. (2007). Lithofacies Summary of the Mississippian Barnett Shale, Mitchell 2 T.P. Sims Well, Wise County, Texas. Bulletin 91, 437-443. doi:10.1306/12040606053

Hu, H., Hao, F., Guo, X., Yi, J., Shu, Z., Bao, H., et al. (2019). Effect of Lithofacies on the Pore System of Over-mature Longmaxi Shale in the Jiaoshiba Area, Sichuan Basin, China. Mar. Pet. Geology. 109, 886-898. doi:10.1016/ j.marpetgeo.2019.06.050

Huang, H., He, D., Li, Y., Li, J., and Zhang, L. (2018). Silurian TectonicSedimentary Setting and basin Evolution in the Sichuan Area, Southwest China: Implications for Palaeogeographic Reconstructions. Mar. Pet. Geology. 92, 403-423. doi:10.1016/j.marpetgeo.2017.11.006

Jiang, Z., Song, Y., Tang, X., Li, Z., Wang, X., Wang, G., et al. (2020). Controlling Factors of marine Shale Gas Differential Enrichment in Southern China. Pet. Exploration Dev. 47, 661-673. doi:10.1016/s1876-3804(20)60083-0

Li, D., Li, R., Tan, C., Zhao, D., Xue, T., Zhao, B., et al. (2019). Origin of Silica, Paleoenvironment, and Organic Matter Enrichment in the Lower Paleozoic Niutitang and Longmaxi Formations of the Northwestern Upper Yangtze Plate: Significance for Hydrocarbon Exploration. Mar. Pet. Geology. 103, 404-421. doi:10.1016/j.marpetgeo.2019.02.025

Li, N., Li, C., Algeo, T. J., Cheng, M., Jin, C., Zhu, G., et al. (2021). Redox Changes in the Outer Yangtze Sea (South China) through the Hirnantian Glaciation and Their Implications for the End-Ordovician Biocrisis. Earth-Science Rev. 212, 103443. doi:10.1016/j.earscirev.2020.103443

Liang, D., Guo, T., Chen, J., Bian, L., and Zhao, Z. (2009). Some Progresses on Studies of Hydrocarbon Generation and Accumulation in marine Sedimentary 
Regions, Southern China (Part 2): Geochemical Characteristics of Four Suits [sic] of Regional marine Source Rocks, South China. Mar. Orig. Pet. Geol. 14 (1), $1-15$.

Liang, Y., Zhang, J., Liu, Y., Tang, X., Li, Z., Ding, J., et al. (2020). Evidence for Biogenic Silica Occurrence in the Lower Silurian Longmaxi Shale in Southeastern Chongqing, China. Minerals 10 (11), 945. doi:10.3390/ $\min 10110945$

Liu, G., Zhai, G., Zou, C., Cheng, L., Guo, X., Xia, X., et al. (2019). A Comparative Discussion of the Evidence for Biogenic Silica in Wufeng-Longmaxi Siliceous Shale Reservoir in the Sichuan basin, China. Mar. Pet. Geology. 109, 70-87. doi:10.1016/j.marpetgeo.2019.06.016

Liu, R., Hao, F., Engelder, T., Zhu, Z., Yi, J., Xu, S., et al. (2020b). Influence of Tectonic Exhumation on Porosity of Wufeng-Longmaxi Shale in the Fuling Gas Field of the Eastern Sichuan Basin, China. Bulletin 104, 939-959. doi:10.1306/ 08161918071

Liu, R., Jiang, D., Zheng, J., Hao, F., Jing, C., Liu, H., et al. (2021a). Stress Heterogeneity in the Changning Shale-Gas Field, Southern Sichuan Basin: Implications for a Hydraulic Fracturing Strategy. Mar. Pet. Geology. 132, 105218. doi:10.1016/j.marpetgeo.2021.105218

Liu, R., Wen, T., Amalberti, J., Zheng, J., Hao, F., and Jiang, D. (2021b). The Dichotomy in noble Gas Signatures Linked to Tectonic Deformation in Wufeng-Longmaxi Shale, Sichuan Basin. Chem. Geology. 581, 120412. doi:10.1016/j.chemgeo.2021.120412

Liu, R., Zheng, J., Hao, F., Nie, Z., Heng, D., Tan, X., et al. (2020a). Variation in Pore Systems with Tectonic Stress in the Overthrust Wufeng-Longmaxi Shale of the Southern Sichuan Basin, China. J. Nat. Gas Sci. Eng. 83, 103617. doi:10.1016/ j.jngse.2020.103617

Liu, X., Lu, Y., Lu, Y., Chen, L., Ma, Y., and Wang, C. (2018). The Application of Geostatistical Inversion in Shale Lithofacies Prediction: a Case Study of the Lower Silurian Longmaxi marine Shale in Fuling Area in the Southeast Sichuan Basin, China. Mar. Geophys. Res. 39 (3), 421-439. doi:10.1007/s11001-0179317-4

Liu, Y., Huang, C., Zhou, Y., Lu, Y., and Ma, Q. (2020c). The Controlling Factors of Lacustrine Shale Lithofacies in the Upper Yangtze Platform (South China) Using Artificial Neural Networks. Mar. Pet. Geology. 118, 104350. doi:10.1016/ j.marpetgeo.2020.104350

Liu, Z., Liu, G., Hu, Z., Feng, D., Zhu, T., Bian, R., et al. (2020d). Lithofacies Types and Assemblage Features of continental Shale Strata and Their Implications for Shale Gas Exploration: A Case Study of the Middle and Lower Jurassic Strata in the Sichuan Basin. Nat. Gas Industry B 7, 358-369. doi:10.1016/ j.ngib.2019.12.004

Long, S., Peng, Y., Lu, J., Zhu, T., Sun, C., and Luo, J. (2021). Identification and Applications of Micro to Macroscale Shale Lithofacies. $j$ nanosci nanotechnol 21, 659-669. doi:10.1166/jnn.2021.18477

Loucks, R. G., and Ruppel, S. C. (2007). Mississippian Barnett Shale: Lithofacies and Depositional Setting of a Deep-Water Shale-Gas Succession in the Fort Worth Basin, Texas. Bulletin 91, 579-601. doi:10.1306/11020606059

Lu, L., Qin, J., Shen, B., Teng, G., Liu, W., and Zhang, Q. (2018). The Origin of Biogenic Silica in Siliceous Shale from Wufeng-Longmaxi Formation in the Middle and Upper Yangtze Region and its Relationship with Shale Gas Enrichment. Earth Sci. Front. 25 (4), 226-236. doi:10.13745/ j.esf.yx.2017-5-5

Lu, Y. B., Ma, Y. Q., Wang, Y. M., and Lu, Y. C. (2017). The Sedimentary Response to the Major Geological Events and Lithofacies Characteristics of Wufeng Formation-Longmaxi Formation in the Upper Yangtze Area. Earth Sci. 42 (7), 1169-1184. doi:10.3799/dqkx.2017.095

Ma, X. (2019). Enrichment Laws and Scale Effective Development of Shale Gas in the Southern Sichuan Basin. Nat. Gas Industry B 6, 240-249. doi:10.1016/ j.ngib.2018.10.005

Mou, C. L., Zhou, K. K., Liang, W., and Ge, X. Y. (2011). Early Paleozoic Sedimentary Environment of Hydrocarbon Source Rocks in the Middle-Upper Yangtze Region and Petroleum and Gas Exploration. Acta Geol. Sin. 85, 526-532.

Nie, H. K., and Zhang, J. C. (2010). Shale Gas Reservoir Distribution Geological Law, Characteristics and Suggestions. J. Cent. South. Univ. 41, 700-708.

Nie, H. K., Zhang, J. C., Xue, H., Long, P. Y., and Wang, G. Y. (2010). Continuous and Discontinuous Accumulations in Hydrocarbon Pooling and Distribution Sequence. Nat. Ind. Gas. 30, 9-14. doi:10.3787/j.issn.1000-0976.2010.09.002
Ou, C., Li, C., Rui, Z., and Ma, Q. (2018). Lithofacies Distribution and GasControlling Characteristics of the Wufeng-Longmaxi Black Shales in the southeastern Region of the Sichuan Basin, China. J. Pet. Sci. Eng. 165, 269-283. doi:10.1016/j.petrol.2018.02.024

Qiu, Z., and Zou, C. (2020a). Controlling Factors on the Formation and Distribution of "Sweet-Spot Areas" of marine Gas Shales in South China and a Preliminary Discussion on Unconventional Petroleum Sedimentology. J. Asian Earth Sci. 194, 103989. doi:10.1016/j.jseaes.2019.103989

Qiu, Z., and Zou, C. N. (2020b). Unconventional Petroleum Sedimentology: Connotation and prospect. Acta Sediment. Sin. 38 (1), 1-29. doi:10.14027/ j.issn.1000-0550.2019.116

Rong, J. Y., Chen, X., Su, Y. Z., Ni, Y. N., Zhan, R. B., Chen, T. E., et al. (2003). Silurian Paleogeography of China. NY State. Mus. Bull. 493, 243-298.

Sahoo, A. K., Mukherjee, D., Mukherjee, A., and Srivastava, M. (2013). Reservoir Characterization of Eagle Ford Shale through Lithofacies Analysis for Identification of Sweet Spot and Best Landing Point. Denver: Unconventional Resources Technology Conference.

Tang, X., Jiang, Z., Huang, H., Jiang, S., Yang, L., Xiong, F., et al. (2016). Lithofacies Characteristics and its Effect on Gas Storage of the Silurian Longmaxi marine Shale in the Southeast Sichuan Basin, China. J. Nat. Gas Sci. Eng. 28, 338-346. doi:10.1016/j.jngse.2015.12.026

Wang, C., Zhang, B., Lu, Y., Shu, Z., Lu, Y., Bao, H., et al. (2018). Lithofacies Distribution Characteristics and its Controlling Factors of Shale in Wufeng Formation-Member 1 of Longmaxi Formation in the Jiaoshiba Area. Pet. Res. 3 , 306-319. doi:10.1016/j.ptlrs.2018.11.005

Wang, D., Rong, J. Y., Tang, P., Huang, B., Zhang, X. L., Xu, H. H., et al. (2021a). Characteristics of Major Hiatus in Middle Paleozoic Rocks of South China and Their Significance of Geotectonics. Sci. Sin. Ter. 51 (2), 218-240. doi:10.1360/ SSTe-2020-0079

Wang, G., Carr, T. R., Ju, Y., and Li, C. (2014). Identifying Organic-Rich Marcellus Shale Lithofacies by Support Vector Machine Classifier in the Appalachian basin. Comput. Geosciences 64, 52-60. doi:10.1016/j.cageo.2013.12.002

Wang, G., and Carr, T. R. (2012a). Marcellus Shale Lithofacies Prediction by Multiclass Neural Network Classification in the Appalachian Basin. Math. Geosci. 44, 975-1004. doi:10.1007/s11004-012-9421-6

Wang, G., and Carr, T. R. (2012b). Methodology of Organic-Rich Shale Lithofacies Identification and Prediction: A Case Study from Marcellus Shale in the Appalachian basin. Comput. Geosciences 49, 151-163. doi:10.1016/ j.cageo.2012.07.011

Wang, G., and Carr, T. R. (2013). Organic-rich Marcellus Shale Lithofacies Modeling and Distribution Pattern Analysis in the Appalachian Basin. Bulletin 97, 2173-2205. doi:10.1306/05141312135

Wang, G., Cheng, G., and Carr, T. R. (2013). The Application of Improved NeuroEvolution of Augmenting Topologies Neural Network in Marcellus Shale Lithofacies Prediction. Comput. Geosciences 54, 50-65. doi:10.1016/ j.cageo.2013.01.022

Wang, G., Jin, Z., Hu, Z., Liu, G., Zhu, T., Du, W., et al. (2021b). Sedimentary Evolution Characteristics of Fine-Grained Lithofacies under the HighResolution Isochronous Shelf System: Insights from the Wufeng-Longmaxi Shales in the Sichuan Basin. Lithosphere 2021, 6628867. doi:10.2113/2021/ 6628867

Wang, H., Shi, Z., Zhao, Q., Liu, D., Sun, S., Guo, W., et al. (2020a). Stratigraphic Framework of the Wufeng-Longmaxi Shale in and Around the Sichuan Basin, China: Implications for Targeting Shale Gas. Energ. Geosci. 1 (3), 124-133. doi:10.1016/j.engeos.2020.05.006

Wang, K., Orth, C. J., Attrep, M., Chatterton, B. D. E., Wang, X., and Li, J.-j. (1993). The Great Latest Ordovician Extinction on the South China Plate: Chemostratigraphic Studies of the Ordovician-Silurian Boundary Interval on the Yangtze Platform. Palaeogeogr. Palaeoclimatol. Palaeoecol. 104, 61-79. doi:10.1016/0031-0182(93)90120-8

Wang, X., Liu, L., Wang, Y., Sheng, Y., Zheng, S., Wu, W., et al. (2020b). Comparison of the Pore Structures of Lower Silurian Longmaxi Formation Shales with Different Lithofacies in the Southern Sichuan Basin, China. J. Nat. Gas Sci. Eng. 81, 103419. doi:10.1016/j.jngse.2020.103419

Wang, Y. M., Wang, S. F., Dong, D. Z., Li, X. J., Huang, J. L., Zhang, C. C., et al. (2016). Lithofacies Characterization of Longmaxi Formation of the Lower Silurian, Southern Sichuan. Earth Sci. Front. 23 (1), 119-133. doi:10.13745/ j.esf.2016.01.011 
Wang, Z., Chen, L., Chen, D., Lai, J., Deng, G., Liu, Z., et al. (2020c). Characterization and Evaluation of Shale Lithofacies within the Lowermost Longmaxi-Wufeng Formation in the Southeast Sichuan Basin. J. Pet. Sci. Eng. 193, 107353. doi:10.1016/j.petrol.2020.107353

Wang, Z. C., Zhao, W. Z., Zhang, L., and Wu, S. X. (2002). Structural Sequence and Natural Gas Exploration in Sichuan Basin. Beijing: Geological Publishing House.

Wei, C., Dong, T., He, Z., He, S., He, Q., Yang, R., et al. (2021). Major, TraceElemental and Sedimentological Characterization of the Upper Ordovician Wufeng-Lower Silurian Longmaxi Formations, Sichuan Basin, south China: Insights into the Effect of Relative Sea-Level Fluctuations on Organic Matter Accumulation in Shales. Mar. Pet. Geology. 126, 104905. doi:10.1016/ j.marpetgeo.2021.104905

Wu, J., Liang, C., Yang, R., and Xie, J. (2021). The Significance of Organic Mattermineral Associations in Different Lithofacies in the Wufeng and Longmaxi Shale-Gas Reservoirs in the Sichuan Basin. Mar. Pet. Geology. 126, 104866. doi:10.1016/j.marpetgeo.2020.104866

Wu, L., Hu, D., Lu, Y., Liu, R., and Liu, X. (2016). Advantageous Shale Lithofacies of Wufeng Formation-Longmaxi Formation in Fuling Gas Field of Sichuan Basin, SW China. Pet. Exploration Dev. 43, 208-217. doi:10.1016/s1876-3804(16) 30024-6

Xu, H., Zhou, W., Hu, Q., Yi, T., Ke, J., Zhao, A., et al. (2021). Quartz Types, Silica Sources and Their Implications for Porosity Evolution and Rock Mechanics in the Paleozoic Longmaxi Formation Shale, Sichuan Basin. Mar. Pet. Geology. 128, 105036. doi:10.1016/j.marpetgeo.2021.105036

Xu, S., Hao, F., Shu, Z., Zhang, A., and Yang, F. (2020b). Pore Structures of Different Types of Shales and Shale Gas Exploration of the Ordovician Wufeng and Silurian Longmaxi Successions in the Eastern Sichuan Basin, South China. J. Asian Earth Sci. 193, 104271. doi:10.1016/j.jseaes.2020.104271

Xu, S., Hao, F., Zhang, Y., and Gou, Q. (2020a). High-quality marine Shale Reservoir Prediction in the Lower Silurian Longmaxi Formation, Sichuan Basin, China. Interpretation 8 (2), T453-T463. doi:10.1190/int-20190149.1

Xu, S., Liu, R., Hao, F., Engelder, T., Yi, J., Zhang, B., et al. (20192019). Complex Rotation of Maximum Horizontal Stress in the Wufeng-Longmaxi Shale on the Eastern Margin of the Sichuan Basin, China: Implications for Predicting Natural Fractures. Mar. Pet. Geology. 109, 519-529. doi:10.1016/ j.marpetgeo.2019.06.008

Yan, D., Li, S., Fu, H., Jasper, D. M., Zhou, S., Yang, X., et al. (2021). Mineralogy and Geochemistry of Lower Silurian Black Shales from the Yangtze Platform, South China. Int. J. Coal Geology. 237, 237103706. doi:10.1016/j.coal.2021.103706

Yang, F., Xu, S., Hao, F., Hu, B., Zhang, B., Shu, Z., et al. (2019). Petrophysical Characteristics of Shales with Different Lithofacies in Jiaoshiba Area, Sichuan Basin, China: Implications for Shale Gas Accumulation Mechanism. Mar. Pet. Geology. 109, 394-407. doi:10.1016/j.marpetgeo.2019.06.028
Yang, X. R., Yan, D. T., Wei, X. S., Zhang, L. W., Zhang, B., Xu, H. W., et al. (2018) Different Formation Mechanism of Quartz in Siliceous and Argillaceous Shales: a Case Study of Longmaxi Formation in South China. Mar. Pet. Geology. 94, 80-94. doi:10.1016/j.marpetgeo.2018.03.036

Zhang, L., Lu, S., Jiang, S., Xiao, D., Chen, L., Liu, Y., et al. (2018). Effect of Shale Lithofacies on Pore Structure of the Wufeng-Longmaxi Shale in Southeast Chongqing, China. Energy Fuels 32, 6603-6618. doi:10.1021/acs.energyfuels.8b00799

Zhao, J. H., Jin, Z. J., Jin, Z. K., Wen, X., Geng, Y. K., and Yan, C. N. (2016b). The Genesis of Quartz in Wufeng-Longmaxi Gas Shales, Sichuan Basin. Nat. Gas Geosci. 27 (2), 377-386. doi:10.11764/j.issn.1672-1926.2016.02.0377

Zhao, J., Jin, Z., Jin, Z., Wen, X., Geng, Y., Yan, C., et al. (2016a). Lithofacies Types and Sedimentary Environment of Shale in Wufeng-Longmaxi Formation, Sichuan Basin. Acta Petrol. Sin. 37, 572-586. doi:10.7623/syxb201605002

Zhu, H., Kong, X., Long, H., and Huai, Y. (2018). Duvernay Shale Lithofacies Distribution Analysis in the West Canadian Sedimentary Basin. IOP Conf. Ser. Earth Environ. Sci. 121, 052007. doi:10.1088/1755-1315/121/5/052007

Zou, C., Dong, D., Wang, S., Li, J., Li, X., Wang, Y., et al. (2010). Geological Characteristics and Resource Potential of Shale Gas in China. Pet. Exploration Dev. 37, 641-653. doi:10.1016/s1876-3804(11)60001-3

Zou, C., Dong, D., Wang, Y., Li, X., Huang, J., Wang, S., et al. (2015). Shale Gas in China: Characteristics, Challenges and Prospects (I). Pet. Exploration Dev. 42, 753-767. doi:10.1016/s1876-3804(15)30072-0

Zou, C., Dong, D., Wang, Y., Li, X., Huang, J., Wang, S., et al. (2016). Shale Gas in China: Characteristics, Challenges and Prospects (II). Pet. Exploration Dev. 43, 182-196. doi:10.1016/s1876-3804(16)30022-2

Zou, C., Qiu, Z., Poulton, S. W., Dong, D., Wang, H., Chen, D., et al. (2018). Ocean Euxinia and Climate Change "Double Whammy" Drove the Late Ordovician Mass Extinction. Geology 46, 535-538. doi:10.1130/G40121.1

Conflict of Interest: QT and GW were employed by PetroChina. The remaining authors declare that the research was conducted in the absence of any commercial or financial relationships that could be construed as a potential conflict of interest.

Publisher's Note: All claims expressed in this article are solely those of the authors and do not necessarily represent those of their affiliated organizations, or those of the publisher, the editors, and the reviewers. Any product that may be evaluated in this article, or claim that may be made by its manufacturer, is not guaranteed or endorsed by the publisher.

Copyright (c) 2021 Tang, Zhou, Chen, Tan and Wang. This is an open-access article distributed under the terms of the Creative Commons Attribution License (CC BY). The use, distribution or reproduction in other forums is permitted, provided the original author(s) and the copyright owner(s) are credited and that the original publication in this journal is cited, in accordance with accepted academic practice. No use, distribution or reproduction is permitted which does not comply with these terms. 